УДК 378.091.39:005.963.2]:373.3

(C) Довженко Т. О., Небитова I. А., Шишенко В. О., 2021 р.

http://orcid.org/0000-0003-1384-511X.

http://orcid.org/0000-0003-3593-9803.

http://orcid.org/0000-0002-3872-3840.

DOI: $10.34142 / 23128046.2021 .51 .08$

Т. О. Довженко,

I. А. Небитова,

В. О. Шишенко

\title{
РОЛЬ МЕНТОРСТВА У ПРОФЕСІЙНІЙ ПІДГОТОВЦІ МАЙБУТНІХ УЧИТЕЛІВ ПОЧАТКОВОЇ ШКОЛИ
}

У статті розкрито роль менторства у професійній підготовиі майбутніх учителів початкової школи.

Метою дослідження є теоретичне обтрунтування ролі менторства $у$ професійній підготовиі майбутніх учителів початкової школи. Використано загальнонаукові (аналіз, узагальнення), порівняльно-зіставний і прогностичний методи наукового пізнання.

На основі аналізу психолого-педагогічної літератури визначено суть понять: «наставництво», «менторство», «ментор», «менти», «коуч», «тьютор», «фасилітатор». Зазначено ступені наставництва: I ступінь педагог-ментор; II ступінь - педагог-тьютор; III ступінь - педагог-коуч; IV ступінь - педагог-фасилітатор. Проаналізовано закордонний досвід впровадження менторства в систему освіти. Визначено переваги менторства для педагога-ментора у $3 B O$ а саме: менторство допомагає досвідченому викладачеві побачити й окреслити нові перспективи в сфері власної педагогічної діяльності; при успішному здійсненні цих функиій ментор відчуває свій внесок у систему професійної адаптаиії менти, отримує задоволення від спілкування; справжній педагог завжди має прагнути до самовдосконалення; виконання функиій ментора може допомогти в розвитку професійної кар'єри педагога, підвищення його кваліфікаиії, сприяе зростанню довіри до нього в педагогічному колективі 3ВО. Охарактеризовано найбільш оптимальні моделі взаємодії, до яких повинен прагнути ментор у професійній підготовиі майбутніх учителів початкової школи: спілкування-корекція (спрямоване на виконання діагностичної функиії ментором); спілкування-підтримка (доречне у ситуаціях, коли необхідно допомогти підопічним у вирішенні складних ситуацій); спілкування - зняття психологічних бар'єрів (передбачає володіння ментором технологією спілкування на досить високому рівні). Визначено роль менторства y професійній підготовиі майбутніх учителів початкової школи під час педагогічної практики. Окреслено переваги і недоліки застосування методу менторства у ЗВО. Доведено, що менторство позитивно впливає як на освітній процес, так і на професійну підготовку майбутніх педагогів. Дружні стосунки, 
психолого-педагогічна підтримка, стимул до професійного розвитку $i$ самовдосконалення є запорукою успішних менторських взаємин.

Ключові слова: майбутні учителі, початкова икола, наставництво, менторство, ментор, менти, коуч, тьютор, фасилітатор .

\section{Dovzhenko T.O., Nebytova I.A., Shyshenko V.O. The role of mentoring in the} training of future primary school teachers. The article reveals the role of mentoring in the training of future primary school teachers.

The purpose of the study is to theoretically substantiate the role of mentoring in the training of future primary school teachers. The general scientific (analysis, generalization), comparative and prognostic and prognostic methods of scientific cognition are used.

On the basis of the analysis of psychological and pedagogical literature the essence of concepts is defined: «mentoring», «mentoring», «mentor», «menti», «coach», "tutor», "facilitator». The degrees of mentoring are indicated: I degree teacher-mentor; II degree - teacher-tutor; III degree - teacher-coach; IV degree teacher-facilitator. The foreign experience of introducing mentoring in the education system is analyzed. The advantages of mentoring for a teacher-mentor in HEI are determined: mentoring helps an experienced teacher to see and outline new perspectives in the field of his / her own pedagogical activity; upon successful implementation of these functions, the mentor feels his contribution to the system of professional adaptation of the police, gets pleasure from communication; a true teacher must always strive for self-improvement; performing the functions of a mentor can help in the development of a teacher's professional career, improving his skills; contributes to the growth of trust in him in the teaching staff of the Free Economic Zone. The most optimal models of interaction, to which the mentor should strive in the professional training of future primary school teachers, are characterized: communication-correction; communication-support; communication - removal of psychological barriers.The role of mentoring in the professional training of future primary school teachers during pedagogical practice is determined. The advantages and disadvantages of using the mentoring method in freelance education are outlined. It has been proven that mentoring has a positive effect on both the educational process and the professional training of future teachers. Friendly relations, psychological and pedagogical support, stimulus to professional development and self-improvement are the key to successful mentoring relationships.

Key words: future teachers, primary school, mentoring, mentoring, mentor, menti, coach, tutor, facilitator.

Вступ. Питання менторства в освіті набуває дедалі більшої актуальності у зв’язку з нестачею кваліфікованих кадрів в українських школах, адже багато молодих педагогів, йдучи працювати в школи, стикаються 3 труднощами, які вони не можуть подолати самостійно. 3 початком педагогічної діяльності молоді вчителі, не отримуючи підтримки від більш досвідчених колег, приходять до 
висновку, що помилилися з вибором професії та змінюють іiі. Менторство у професійній підготовці майбутніх учителів початкової школи покликане вирішити проблему передчасного завершення кар'єри педагога. Процес менторства передбачає тісний контакт досвідченого педагога-наставника i майбутнього вчителя в процесі його професійної підготовки з метою вирішення проблемних ситуацій, подолання криз і підвищення продуктивності процесу навчання в умовах освітнього простору ЗВО.

Мета та завдання. Мета дослідження - теоретично обгрунтувати роль менторства у професійній підготовці майбутніх учителів початкової школи. Завдання: визначити відмінність між поняттями «наставництво» та «менторство»; проаналізувати закордонний досвід впровадження менторства в систему освіти; визначити оптимальні моделі взаємодії, до яких повинен прагнути ментор у професійній підготовці майбутніх учителів початкової школи; обгрунтувати роль менторства у професійній підготовці майбутніх учителів початкової школи під час педагогічної практики.

Методи дослідження. Під час дослідження використано комплекс методів, а саме: загальнонаукові (аналіз, узагальнення), що стали основою для визначення ступеня розробки проблеми; порівняльно-зіставний - забезпечив можливість порівнювати й зіставляти думки науковців щодо проблеми дослідження; прогностичний - дозволив окреслити перспективи менторства в сучасній освітній практиці професійної підготовки майбутніх учителів початкової школи.

Результати. Аналіз психолого-педагогічної літератури дозволив дійти висновку, що менторство і наставництво $є$ схожими, але не тотожними поняттями.

Зауважимо, що Я. Коменський вважав, що в основі педагогічного наставництва закладений принцип індивідуального підходу, який передбачає врахування вікових та індивідуальних особливостей здобувачів освіти. Педагог працює фронтально, а здобувачі засвоюють знання індивідуально. Основний зміст цього принципу - знайти дієві способи передачі знань здобувачам, враховуючи їх індивідуальні особливості.

Педагог С. Батишев вважає менторство одним із ступенів наставництва. Так, дослідник пропонує нові технології педагогічного наставництва розділити на чотири ступені (Batishev, 2016):

I ступінь наставництва - педагог-ментор (від лат. Mentos - намір, мета, дух, mon-i-tor - той, хто наставляє) - керівник, учитель, наставник, вихователь. Менторство передбачає цілеспрямовану передачу досвіду здобувачеві більш досвідченим наставником за типом наслідування. 
II ступінь наставництва - педагог-тьютор (від лат. Tutorem - наставник, опікун) - в значенні «старший, призначений опікати здобувача в процесі навчання». «Тьюторінг» спрямований на супровід процесу навчання, обговорення досвіду перенесення отриманих знань у реальну практику.

III ступінь наставництва - педагог-коуч (англ. Couch - тренер) - це досвідчений наставник, здатний будувати процес навчання на основі партнерських взаємовідносин, надихати підопічних на самостійний пошук вирішення проблем. «Коучинг» забезпечує розкриття потенціалу особистості здобувача.

IV ступінь наставництва - педагог-фасилітатор (англ. Facilitator, від лат. Facilis - легкий, зручний) - це досвідчений керівник, який забезпечує успішну групову комунікацію на основі креативних моделей корпоративного навчання.

У зарубіжній літературі використовується термін «менторство» для позначення явища наставництва. За визначенням словника сучасної англійської мови видавництва Кембридж - менторство - це дія або процес надання допомоги молодшому або менш досвідченому колезі в професійній або навчальній діяльності. Ментор - це людина, яка надає допомогу і підтримку менш досвідченому колезі в певний період часу. Той, хто отримує цю підтримку, називається менти або підопічний. Ментор - це порадник 3 професійним досвідом, який бажає ним поділитися; людина, яка надихає морально й емоційно; учитель, який може дати адекватну професійну оцінку діям свого менти; взірець, у якого можна і потрібно вчитися; джерело інформації і помічник на шляху до досягнення цілей; ідеал, до якого потрібно прагнути, щоб стати вчителем (Morris, 1995).

За кордоном менторство широко використовується як ефективний спосіб підготовки молодих педагогів до професії, тому що сприяє не тільки професійному росту самого новачка, але і продуктивній діяльності його учнів. Про це в своїх наукових доробках писали С. Оделл та Дж. Ферраро (Odell \& Ferraro, 1992).

А. Малдерз визначає менторство в широкому сенсі як підтримку, яку надають одним колегою (в основному більш досвідченим) іншому і спрямовану на навчання, зростання й інтеграцію новачка в професійне середовище (Malderez, 2001).

А. Сміт стверджує, що менторство полягає не тільки в підтримці, а й у створенні певних умов для прогресу менти (Smith, 2007).

С. Фербенкс, Д. Фрідман і К. Кан визначають менторство над молодими педагогами як комплексну взаємодію між ментором і менти, спрямовану на досягнення професійних цілей у контексті виникаючих обставин (Fairbanks, Freedman \& Kahn, 2000). 
Менторство - це персональна підтримка недосвідченого педагога досвідченим, яка спрямована на професійний розвиток новачка, його становлення частиною колективу і адаптацію до умов роботи в конкретному закладі освіти (Andrew, Hobson, Ashby, Malderez \& Peter, 2013).

Процес професійної підготовки майбутніх учителів початкової школи має бути спрямований на навчання їх новим ідеям і підходам в освіті для підвищення власного професійного потенціалу, так як саме вони зможуть модернізувати навчальний процес, щоб зробити його більш успішним.

Менторство є тривалим процесом створення довірливих, особистісно зацікавлених взаємин між ментором і підопічним, що спрямований на досягнення у останнього суттєвої динаміки в удосконаленні знань, мислення, практичних дій, з метою його професійного становлення як цілісної особистості педагога.

У процесі менторства ментор добровільно ділиться власним досвідом і знаннями, а підопічні розвивають свої професійні навички і шукають шляхи вирішення проблем з метою досягнення істотних змін в професійній діяльності.

Беручи на себе обов'язки ментора, педагог відкриває для себе ряд переваг:

- по-перше, менторство допомагає досвідченому викладачеві побачити й окреслити нові перспективи в сфері власної педагогічної діяльності; - $\quad$ по-друге, при успішному здійсненні цих функцій ментор відчуває свій внесок в систему професійної адаптації менти, отримує задоволення від спілкування;

- по-третє, справжній педагог завжди має прагнути до самовдосконалення;

- $\quad$ по-четверте, виконання функцій ментора може допомогти в розвитку професійної кар'єри педагога, підвищення його кваліфікації; сприяє зростанню довіри до нього в педагогічному колективі ЗВО (Bondarenko \& Tokar, 2007).

Слід зазначити, що найбільш оптимальними моделями взаємодії, до яких повинен прагнути ментор у професійній підготовці майбутніх учителів початкової школи, є:

- спілкування-корекція. Цей вид спілкування спрямований на виконання діагностичної функції ментором. Спілкування-корекція вимагає від ментора знання психолого-педагогічної теорії, володіння прийомами діагностичного дослідження, спеціальних знань у галузі технології спілкування;

- спілкування-підтримка. Зазначений тип спілкування доречний у ситуаціях, коли необхідно допомогти підопічним у вирішенні складних ситуацій, з якими вони не можуть впоратися самостійно. Від ментора вимагається не 
тільки сукупність знань, а й мобілізація таких особистісних якостей, як емпатія, такт, чуйність тощо;

- спілкування - зняття психологічних бар'єрів. Цей тип спілкування передбачає володіння ментором технологією спілкування на досить високому рівні, наявність у нього потреби в спілкуванні з підопічними, бажання допомогти їм у встановленні відносин довіри (Rukovodstvo dlya uchitelya pervogo (prodvinutogo urovnya), 2014).

Спираючись на вищезазначене, розглянемо роль менторства у професійній підготовці майбутніх учителів початкової школи під час педагогічної практики.

Менторство - це техніка, яка дозволяє передавати знання, вміння і досвід в атмосфері підтримки, беручи до уваги певні труднощі для майбутніх учителів початкової школи у процесі педагогічної практики. Розуміння цієї ключової відмінності наставництва і менторства багато в чому обумовлює і різницю в методах роботи 3 підопічними, які в менторстві називаються «менти» (Nastavnitstvo, mentoring, 2021).

Основні вимоги до «менти» (підопічного) - готовність прийняти те, що дає ментор, здатність до педагогічної діяльності, наявність бажання працювати 3 дітьми тощо. Умовами успішного менторства для пари «ментор - менти» $є$ конструктивні відносини співпраці, комфортний для обох ритм і стиль взаємодії, наявність взаємної симпатії і поваги (конфлікти не виключені, але вони мають бути конструктивними), регулярність зустрічей. Форми взаємодії ментора i «менти»- особисті зустрічі та інші види спілкування.

У менторстві не можна однозначно сказати, що один навчає, а інший навчається (у наставництві це очевидно, а в менторстві цього немає). Ментор, систематизуючи передану інформацію і задаючи питання для роздуму своєму підопічному, може по-новому побачити ситуацію щодо організації педагогічної діяльності, зробити певні висновки та прийняти важливі рішення (Kruglova, 2009).

Слід зазначити, що менторство у професійній підготовці майбутніх учителів початкової школи під час педагогічної практики варто розпочинати 3 постановки конкретних цілей і завдань. Одним із таких завдань може бути сприяння професійному розвитку майбутніх педагогів, завдяки чому вони зможуть самостійно і відповідально виконувати професійні обов'язки.

Процес менторства досить об’ємний і послідовний, тому слід ретельно планувати етапи роботи з менти, після чого впроваджувати нові підходи в практику підопічних: перший етап - ознайомлення менти 3 методикою менторства; другий етап - відвідування пробних і залікових уроків менти 3 подальшим обговоренням; третій етап - обговорення уроку разом з менти, який буде проводити ментор. На уроці доцільно демонструвати ті зміни в практиці, 
які були запропоновані підопічними, зокрема: спільне цілепокладання, організація групової роботи, застосування формативного оцінювання; робота 3 обдарованими дітьми; застосування прийомів для розвитку критичного мислення; заповнення листів саморефлексії тощо.

Зауважимо, що і сам ментор у процесі менторства набуває навичок спостереження за підопічними 3 певною метою, а саме: аналіз на основі спостережень; систематизування і дослідження власної діяльності в якості ментора; виявлення проблем 3 метою їх подальшого вирішення; створення атмосфери співпраці; коригування переконань (своїх i менти) на основі отриманого досвіду тощо.

Спираючись на вищезазначене можемо стверджувати, що менторство відрізняється від традиційного наставництва тим, що цей процес обов'язково є двостороннім. I ментор, і менти отримують кожен свій результат, загальний - у постановці єдиних цілей і завдань, і індивідуальний - у практичній діяльності (Zakablutskaya, 2021).

Доцільно підкреслити, що під час застосування менторства у ЗВО необхідно врахувати як переваги, так і недоліки цього методу. 3 одного боку, доброзичлива, демократична позиція, готовність до діалогу й обговорення можуть зробити спілкування в процесі навчання більш щирим, дозволити майбутнім учителям початкової школи відчувати себе впевнено, пропонувати нові, незвичайні способи вирішення навчальних завдань. 3 іншого боку, такий стиль передачі інформації може викликати проблеми 3 дисципліною, відповідальністю і своєчасним виконанням завдань здобувачами.

Якщо проаналізувати діяльність, здійснювану ментором у процесі реалізації своїх функцій, то можна виділити основні кроки, властиві його роботі. До них належать: аналіз і оцінка перспективи розвитку майбутніх учителів початкової школи, допомога в постановці цілей і розробці шляхів їх досягнення, демонстрація власного прикладу в реалізації завдань, психологічна підтримка, постановка практичних завдань, які допоможуть оволодіти педагогічною діяльністю, контроль за їх виконанням, оцінка та рекомендації для подальшої діяльності.

У процесі діяльності викладача-ментора особлива увага приділяється індивідуальним завданням, які він надає здобувачам. Так, якщо викладач стає ментором у кількох здобувачів, то він розробляє окремий комплекс завдань, враховуючи індивідуальні особливості кожного із підопічних.

Функція психологічної підтримки, що входить до обов’язків ментора, дозволяє обговорювати успішність освітнього процесу: що мотивує, а що заважає роботі; страхи і сумніви, які хвилюють майбутнього педагога. Таким чином, встановлюються відносини довіри в діаді «ментор - менти», які зможуть 
підвищити ефективність професійної підготовки майбутніх учителів початкової школи.

Обговорення. Метод менторства передбачає реалізацію чотирьох основних етапів: підготовка, обговорення, уповноваження та завершення. Початкові етапи пов'язані 3 підготовкою та обговоренням процесу роботи i необхідні для створення атмосфери довіри, постановки цілей і завдань, спільних дій, затвердження графіка зустрічей, формування уявлень у обох сторін про взаємні очікування і результати процесу навчання. Далі йде виконання самої роботи, в процесі якої ментор підтримує професійне зростання майбутнього вчителя початкової школи, допомагає йому в рефлексії власних дій, оцінює та коригує виконання завдань. На цьому етапі особливого значення набуває те, наскільки довірливі відносини були «побудовані» на початку роботи і чи виходить у ментора створити щирий і відкритий діалог зі своїм підопічним. Нарешті, менторство може стати відповідним методом роботи як в процесі навчання, так і в період проходження майбутніми вчителями початкової школи педагогічної практики, а також під час написання ними випускної кваліфікаційної роботи.

Менторство полягає в організації освітнього середовища, що побудоване на постійному рефлексивному співвіднесенні досягнень 3 інтересами i бажаннями. Педагог-ментор створює освітнє середовище, що насичене безліччю пропозицій, які потенційно можуть бути цікаві підопічному. Після цього ментор здійснює навігацію руху менти в цьому просторі пропозицій, обговорюючи різні стратегіï (Kruglova, 2009).

М. Зембицький зазначає, що в сфері менторства створюються соціальнопедагогічні умови для успішного навчання та особистісного розвитку майбутнього вчителя. В якості ментора виступає педагог, а менторство $\epsilon$ особливою формою діяльності викладача, що спрямована на взаємодію, надання допомоги молодому фахівцеві в процесі його професійної підготовки та особистісного зростання (Zembitskaya, 2014).

Висновки. Отже, в результаті порівняльного аналізу підходів до визначення наставництва в Україні і за кордоном, можна зробити висновок, що терміни «наставництво» і «менторство» однакові за своєю суттю, але мають ряд відмінностей в силу особливостей систем освіти і підходів до організації діяльності педагогів. Більшість закордонних (зокрема американських) дослідників роблять акцент на тому, що в процесі менторства майбутній педагог вчиться професії зсередини. Але лише в небагатьох напрацюваннях українських дослідників йдеться про цю перевагу. Вітчизняний підхід до менторства можна назвати більш формальним, тому що часто виділяються такі необхідні ознаки ментора, як досвід роботи не менше п’яти років, вища кваліфікаційна категорія 
тощо. Закордонні вчені фокусуються на бажанні та можливості ментора провадити цю діяльність. Звичайно, ментор повинен мати певний досвід роботи в цій сфері, але ніяких жорстких кількісних вимог дослідники не пропонують.

Зауважимо, що вітчизняні і зарубіжні науковці говорять про позитивний вплив менторства як на освітній процес, так i на професійну підготовку майбутніх педагогів. Дружні стосунки, психолого-педагогічна підтримка, стимул до професійного розвитку і самовдосконалення є запорукою успішних взаємин у менторської пари. Учасники менторських відносин отримують i приносять користь один одному, що позитивно відбивається на їхній педагогічній діяльності та професійному становленні.

\section{ЛІТЕРАТУРА:}

Andrew J. Hobson, Patricia Ashby, Angi Malderez, Peter D. Tomlinson Corrigendum to «Mentoring beginning teachers: What we know and what we don't» Teaching and Teacher Education, Volume 31. 2013.

Malderez A. New ELT professionals, English Teaching Professional. 2001.

Morris Zelditch in a 1990 speech to the Western Association of Graduate Schools Gaffney. P. 1. 1995.

Odell S., Ferraro D. Teacher Mentoring and Teacher Retention. Journal of Teacher Education, 43(3). 1992.

Smith A. Mentoring for experienced school principals: Professional Learning in a safe place. Mentoring and Tutoring, 15 (3). 2007.

Fairbanks C., Freedman D., Kahn C. The role of effective mentors in learning to teach. Journal of Teacher Education, 51(2). 2000. P. 102-112.

Батышев С. Педагогические основы наставничества. М: Материалы теоретической конференции, Ч.1. 2016.

Бондаренко Н., Токарь А. Наставничество. 2007. URL http://www.rusnauka.com/15_NNM_2012/Pedagogica/ (дата звернення: 07.07.2021).

Закаблуцкая Е. Молодой специалист и наставник - премудрости тандема. URL : http://www.artmanage.ru/articles/molodojspecialist-i-nastavnik.html (дата звернення: 07.07.2021).

Зембицкая М. Поддержка молодых учителей как приоритет кадровой политики США в сфере школьного образования. Актуальные проблемы гуманитарных и естественных наук. №2. 2014.

Круглова И. Организация наставничества в школе. Справ. зам. директора шк. №1. 2009.

Наставництво, менторинг. URL: http://formatta.ru/pages/id/317 (дата звернення: 07.07.2021).

Руководство для учителя первого (продвинутого уровня). AOO «НИШ» Центр педагогического мастерства. Второе издание. 2014.

\section{REFERENCES:}

Andrew J. Hobson, Patricia Ashby, Angi Malderez, Peter D. (2013). Tomlinson Corrigendum to «Mentoring beginning teachers: What we know and what we don't» Teaching and Teacher Education, Volume 31.

Batyishev S. (2016). Pedagogicheskie osnovyi nastavnichestva [The pedagogical foundations of mentoring]. M.: Materialyi teoreticheskoy konferentsii, ch.1. (in Russian). 
Bondarenko N., Tokar A. (2007). Nastavnichestvo [Mentoring]. URL : http://www.rusnauka.com/15_NNM_2012/Pedagogica/ (data zvernennya: 07.07.2021) (in Russian).

Fairbanks C., Freedman D., Kahn C. (2000). The role of effective mentors in learning to teach. Journal of Teacher Education, 51(2).

Kruglova I. (2009). Organizatsiya nastavnichestva v shkole [Organization of mentoring at school]. Sprav. zam. direktora shk. \#1. (in Russian).

Malderez A. (2001). New ELT professionals, English Teaching Professional.

Morris Zelditch in a 1990 speech to the Western Association of Graduate Schools Gaffney. (1995). P. 1.

Nastavnitstvo, mentoring (n. d.). [Mentoring]. URL : http://formatta.ru/pages/id/317 (data zvernennya: 07.07.2021) (in Ukrainian).

Odell S., Ferraro D. (1992). Teacher Mentoring and Teacher Retention. Journal of Teacher Education, 43(3).

Rukovodstvo dlya uchitelya pervogo (prodvinutogo urovnya) (2014). [First (advanced) teacher's guide]. AOO «NISh» Tsentr pedagogicheskogo masterstva. Vtoroe izdanie (in Russian).

Smith A. (2007). Mentoring for experienced school principals: Professional Learning in a safe place. Mentoring and Tutoring, 15 (3).

Zakablutskaya E. Molodoy spetsialist i nastavnik - premudrosti tandema [Young specialist and mentor - tandem wisdom]. URL : http://www.artmanage.ru/articles/molodojspecialist-inastavnik.html (data zvernennya: 07.07.2021) (in Russian).

Zembitskaya M. (2014). Podderzhka molodyih uchiteley kak prioritet kadrovoy politiki SShA v sfere shkolnogo obrazovaniya [Supporting Young Teachers as a Priority for USA Personnel Policy in School Education]. Aktualnyie problemyi gumanitarnyih $i$ estestvennyih nauk. \#2 (in Russian).

\footnotetext{
Інформація про авторів:

Довженко Тетяна Олексіївна:

ORCID: 0000-0003-1384-511X.

Доктор педагогічних наук, професор, декан факультету початкового навчання, Харківський національний педагогічний університет імені Г.С. Сковороди, Харків 61002, вул. Алчевських 29, Україна

e-mail: tatanadovzhenko@gmail.com

\author{
Небитова Ірина Андріївна: \\ ORCID: 0000-0003-3593-9803 \\ початкової і професійної освіти, \\ координатор $з$ виховної роботи факультету \\ початкового навчання, Харківський \\ національний педагогічний університет \\ імені Г.С. Сковороди, Харків 61002, вул. \\ Алчевських 29, Україна. \\ e-mail: nebytova.iryna@gmail.com
}

Доктор філософії, викладач кафедри
}

Шишенко Валентина Олексіївна:

ORCID: 0000-0002-3872-3840

\section{Information about the authors: Dovzhenko Tetyana Oleksiivna: ORCID: 0000-0003-1384-511X.}

Doctor of Pedagogical Sciences, Professor, Dean of the Faculty of Elementary Education, H.S. Skovoroda Kharkiv National Pedagogical University, 29 Alchevskykh Street, Kharkiv 61002, Ukraine.

e-mail: tatanadovzhenko@gmail.com

\section{Nebytova Iryna:}

ORCID: 0000-0003-3593-9803.

Doctor of Philosophy, Teacher of the Department of Elementary and Professional Education, Deputy Dean for Educational Work, H.S. Skovoroda Kharkiv National Pedagogical University, 29 Alchevskykh Street, Kharkiv 61002, Ukraine

e-mail: nebytova.iryna@gmail.com

Shishenko Valentina:

ORCID iD 0000-0002-3872-3840. 
Кандидат педагогічних наук, доцент, доцент кафедри початкової і професійної освіти, Харківський національний педагогічний університет імені Г.С. Сковороди, Харків 61002, вул. Алчевських 29, Україна

e-mail: valentina_sh@meta.ua
Candidate of Pedagogical Sciences, Associate Professor, Associate Professor of the Department of Elementary and Professional Education, H.S. Skovoroda Kharkiv National Pedagogical University, 29 Alchevskykh Street, Kharkiv 61002, Ukraine

e-mail: valentina_sh@meta.ua

Цитуйте цю статтю як: Довженко Т. О., Небитова І. А., Шишенко В. О. Роль менторства у професійній підготовці майбутніх учителів початкової школи. Теорія та методика навчання та виховання. 2021. № 51. С. 77-87.

DOI: $10.34142 / 23128046.2021 .51 .08$

Дата надходження статті до редакції: 29.09.2021 p.

Стаття прийнята до друку: 12.09.2021 р. 